rい。

気管気管支粘膜に綎走する䜵譬が著明であつ たが、これは老人性変化あるいは慢性炎症によ るという報告があるが, ${ }^{10}$ 本所見がアンモニア 中毒に特徴的であるか, あるいは急性中毒後遺 症としての慢性気管支炎によるものであるかは 不明である。

患者を仰臥位で気管支鏡検查した際，呼気時 飞，気管気管支壁が内方に陥凹し，前後方向の 内径が短縮することが認められた。正常人でも 気管後壁は膜性部であり, 呼気時に内径及び長

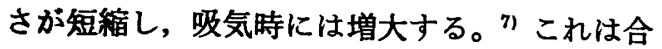
目的的に解釈すると, 死腔を堿少させるためで あろ5と思われるが, この例のように残気量が 大きい場合は，有効であろ5。この内径の変化 は，喘息ではいちぢるしい呼気時の胸腔内圧上 昇によるとされ，気管支周囲の圧が高まつてい るとい5。 ${ }^{78)}$ 狭窄部を気流速度大なる呼気が 通過する場合, ベルヌーイ効果の如き要因で, 特に附近の圧が低下し, 内径が狭小化すること も考えられる。気管支後壁が内腔にむけて宿凹 するのは, 気管の弾性が低下し, 軟骨が硬化し たことによるといら報告もあるが，検查時の患 者の体位による重力の呼吸運動に及ぼす影響も 考えるべきである。

\section{桔 語}

アンモニアガス吸入による中毒災害は非常に 稀なものである。我々は二例の患者について， 呼吸機能検查, 気管支鏡検查から, 主として呼 吸器におこつた障害の後遗症について追求し た。この中毒症では気管気管支は強く障害をう けているが, 肺胞は比較的障害の度が少く, こ
の後遣症の本態は慢性炎症による気管支狭窄が 主であることを推論した。また，気管支粘膜が 縦の解壁を形成し, 呼気時に気管内径がつよく 短縮し, 特に前後径の変化が著明であることを 報告した。

稿を終るに臨み御校閲を睗つた切替一郎教授に深 く感謝いたします。また，御協力をいただいた，東 大病院内科深須新一郎先生及び老年病学科村尾裕史 先生に謝意を表します。

\section{文 献}

1) H. Hinshaw and L. Garland: Diseases of the chest, p. 679 Saunders, 1956

2) 理化学辞典, 岩波 1965

3) D. Hunter:The diseases of occupations, p. 652 The English University Press, 1964

4) R. Johnstone and S. Miller : Occupational diseases and industrial medicine, p. 105-146

E \& S Livingstone, 1951

5) K. Perry and T. Sellors:Chest diseases Vol 1. p. 511 Butterworths, 1963

6) V. Negus: The comparative anatomy and physiology of the larynx, p. 59-72 Hafner, 1962 7) G.L. Restrepo and B.E. Heard: Air trapping in chronic bronchitis and emphysema, Am. Rev. Resp. Dis. 90: 395. 1964

8) A. H. Campbell and I. F. Young : Tracheobronchial Collapse: Variant of obstructive respiratory disease, Brit. J. Dis. Chest 57: 174, 1963

9) A. J. Cracovaner:Stenosis after explosion of Lithium Hydride Arch. Otolaryng. 80: 87-92, 1964

10）潼野賢一坂口幸雄：直達鎮下にみられる気管 支粘膜綎毁の臨床的意義, 気食会報 $16: 272-275$, 1965

\author{
訂 正 \\ 17巻 5 号 P 22 25「末期気管支滔に対する気管支鏡下Rd 針刺入 \\ 経験 川久保淳他」 \\ 文中 Rd針を Rn seeds に訂正，p22 6 行目 $\gamma$ を R に訂正。
}

